\title{
"EDUCAÇÃO ATIVISTA NA CIBERCULTURA: EXPERIÊNCIAS PLURAIS NAS REDES EDUCATIVAS"
}

\author{
Andrea Lapa (UFSC) \\ Cristiane Porto (UNIT/ITP) \\ Maria Luiza Oswald (UERJ) (Orgs.) \\ "às vezes eu falo com a vida, \\ às vezes é ela quem diz, \\ qual a paz que eu não quero conservar pra tentar ser feliz".
}

(Minha alma, O Rappa)

Estamos vivendo hoje em sobressalto. Assistimos, estupefatos, forças antidemocráticas ecoando pelas bocas das pessoas e pelo que expressam através de suas redes sociais, em posts que não se preocupam em ter lastro de verdade, ou cuidado com o outro. Assustados, observamos o regime democrático brasileiro ser corroído por dentro, evidenciando, infelizmente, que somos um país socialmente fascista. Uma democracia de baixa intensidade, como diz Boaventura Santos, e que escorrega para a antidemocracia.

A comunicação que é feita, seja pelos líderes do governo, pelas mídias ou pelas pessoas comuns, legitima este jogo de forças e potencializa manifestações de intolerância, discriminação e violência. A barbárie é naturalizada como um filme hollywoodiano em nosso quintal. A violência como a expressão de uma guerra travada contra o próprio povo, que desnuda o patriarcado e o colonialismo que permanecem dando cores às desigualdades sociais em um mundo dominado pelo capitalismo financeiro. Um fenômeno que tensiona e condiciona um futuro democrático em escala internacional, que, todavia, parece mais evidente e latente no Brasil.

Diante da atual conjuntura de enfraquecimento democrático, vemos ampliada a importância da educação. A aposta em uma educação de qualidade implica dar ênfase aos espaços de formação de sujeitos para o pleno desenvolvimento humano e para a cidadania, conforme preconizado na Constituição Federal Brasileira (art. 205) para além da capacitação para o trabalho. Daí que a educação ganha destaque como espaço de formação para a emancipação social e, por isso, também, o espaço controlado e o novo campo de guerra das forças antidemocráticas. Entre a potencialidade de transgressão e escape e as forças estratégicas de controle e reprodução do status quo, está a escola e os profissionais da educação, buscando brechas, alternativas e oportunidades.

Daí se evidencia como a área da Educação torna-se um lugar especial e singular, tanto para revelar os conflitos e tensões postos na prática, como para refletir e apontar alternativas de espírito 
mais democrático com potência para a transformação pessoal e social. Essas implicações políticas e sociais contemporâneas são intensificadas pela imersão, inevitável, de todos e todas no contexto da Cibercultura, o que agrega enormes desafios para se pensar na educação do século XXI.

Um primeiro e importante passo seria reconhecer a reconfiguração da indústria cultural em tempos de internet e redes sociais. Essas que, tanto ampliam as formas de participação social em plataformas de comunicação horizontal e bidirecional, como expõem as pessoas, de dentro de casa e da palma da mão, a novos riscos dados pela difusão desenfreada de desinformação e da polarização que resulta em mais intolerância e discurso de ódio nas redes e nas ruas. Portanto, atualizar a formação para a leitura crítica das mídias permanece uma demanda urgente que educadores não podem menosprezar.

Contudo, um segundo passo, similarmente imprescindível, seria encontrar brechas de possibilidade para subverter a lógica programada que, apesar dos espaços mais democráticos da Cibercultura, insistem em promover a reprodução das mesmas formas de controle social sob nova roupagem. Trata-se, daí, da possibilidade de uma apropriação crítica e criativa das mídias segundo objetivos que sejam mais humanos e sociais.

O contexto da Cibercultura traz como demanda para as escolas uma educação que esteja vinculada e comprometida com ela. E, evidentemente, uma formação de professores que inclua a Cibercultura em seu cotidiano, fomentando que se reconheçam como docentes reflexivos e ativistas em processos permanentes de experimentação e autoformação no cotidiano educativo que integra as mídias já presentes na vida cotidiana fora da escola.

Se por um lado os desafios são mais evidentes, não se pode desconsiderar que há na escola uma efervescência que merece estudo. O ativismo político destes tempos temerosos se sobressaiu na educação, por exemplo, na primavera secundarista e na ocupação, das escolas e das ruas, por jovens que se uniram na indignação e na esperança por uma educação de maior qualidade. Também, nas greves discentes que afloram pelo Brasil contra os cortes orçamentários e a asfixia promovida nas universidades e na pesquisa científica do País. Jovens que, a partir de processos democráticos, de decisão e ação, lutam por um futuro que está em risco.

Por essa razão, o campo da educação precisa se debruçar sobre as experiências inovadoras e plurais que apontam alternativas, de modo a promover a necessária reflexão que seja, igualmente, comprometida com a resistência e a luta por um país mais democrático e menos injusto. Porque acreditamos, e buscamos a possibilidade, de que a educação que se pretende emancipatória será, inevitavelmente, uma educação ativista na Cibercultura. 
Importante salientar que, este dossiê foi pensado como um dos produtos do Projeto de Mobilidade Acadêmica intitulado - Desafios para a pesquisa, a formação docente e as aprendizagens na educação básica na Cibercultura em tempo de app-learning - apoiado pela Coordenação de Aperfeiçoamento de Pessoal de Nível Superior (CAPES) e pela Fundação de Apoio à Pesquisa e à Inovação Tecnológica do Estado de Sergipe (FAPITEC/SE). Por contarmos no elenco de autores com Bolsistas de Produtividade em Pesquisa do Conselho Nacional de Desenvolvimento Científico e Tecnológico (CNPq), destacamos a importância deste como apoiador e fomentador de pesquisa

O que é a proposta desta coletânea. Este dossiê da Revista Teias compila estudos, pesquisas e práticas que veêm tensionar e dar visibilidade às formas de resistência e luta presentes no cotidiano educacional. Visa, de igual modo, apresentar propostas que apontem alternativas latentes para uma educação emancipadora na Cibercultura.

Os artigos reunidos aqui tratam da questão deste dossiê em distintos âmbitos, os quais procuramos apresentar brevemente a seguir. Para começar, são tratadas algumas questões de fundamento. Isabel Colucci Coelho mergulha na atual conjuntura de esgarçamento democrático da atualidade para problematizar a educação neste contexto que traz desafios mas também oportunidades. Depois, Andrea Lapa, Lucrezia Lanna e Sabrina Silva defendem uma proposta de metodologia de pesquisa ativista como princípio para o papel do professor e do pesquisador na atualidade, a qual problematizam dentro do escopo de um projeto de educação em direitos humanos com integração de TIC em uma perspectiva produtora e colaborativa.

Em seguida, mergulhamos em artigos que trazem à luz algumas experiências e pesquisas sobre questões provocadoras colocadas pelos novos espaços da Cibercultura, onde se engendram novas formas de comunicação e relacionamento social. É o caso da pedagogia decolonial de mulheres vlogueiras no Youtube, tratada por Tatiana Santos da Paz e Eduardo Santos Junqueira Rodrigues, ou a visibilidade de blogs feministas no Tumblr, trazida por Quesia Silva do Carmo e Edvaldo Souza Couto. Outro tema instigante trazido à baila é o da formação de si (bildung) pensada no campo da educação, tema este avocado por Verônica Alves Conceição, Jonathas Fontes Santos e Cristiane Magalhães Porto. Para fechar este bloco temos Alexandre Meneses Chagas, Murilo Santos Lacerda e Ronaldo Nunes Linhares introduzindo e defendendo a aprendizagem colaborativa como prática emancipadora da cibereducação.

$\mathrm{Na}$ sequência há dois artigos que tratam, diretamente, das violências na Cibercultura. O primeiro, de Adriane Gomes Araújo Costa e Alessandra Alexandre Freixo procura fazer uma 
cartografia da violência de gênero nas redes sociais, compreendendo o Facebook como espaço educativo empoderador. E o segundo, de Telma de Brito Rocha, busca refletir sobre a educação para a prevenção de violências, estudando ações educativas contra o ódio nas redes sociais.

Um terceiro grupo de artigos foca mais especificamente no ensino de língua inglesa com TIC. O texto de Mariana Lettieri Ferreira e Lucila Pesce vai se desdobrar sobre o netativismo, defendendo a internet como espaço possível da ação educadora, estudando os memes em vivências formativas. Enquanto o artigo de Eloisa Figueiredo Semblano Gonçalves, Carla Sena dos Santos Pina e Maria Luiza Magalhães Bastos Oswald vai propor que a aprendizagem do inglês em rede pode se constituir numa perspectiva ativista da educação.

A seguir, trazemos dois textos propositivos da educação hacker como alternativa de empoderamento cidadão e ativismo na educação. Primeiramente, com a proposta da Pirâmide da Pedagogia Hacker com a sistematização de um levantamento do potencial educativo de hackerspaces realizado por Karina Menezes e Nelson Pretto. E depois com o texto em espanhol de Alexandre Aguado e Isabel Canovas, que aprofundam na concepção inovadora da educação hacker para apontar caminhos para a auto reflexão, as práticas, o currículo e as políticas inovadoras.

O dossiê finaliza com o texto de Aníbal Guerreiro, Daniela Melaré Vieira Barros e Lina Morgado que, com o objetivo de potenciar o ensino à distância, apresenta pesquisa bibliográfica e documental sobre os agentes inteligentes e sua importância pedagógica para a tutoria na educação on-line.

Esperamos que esta publicação contribua para pesquisas e práticas inovadoras que, simultaneamente, estão engajadas na construção de um futuro tangível para todos nós. Boa leitura! 